\title{
The effects of green tea (Camellia sinensis) flower extract on melanin synthesis in B16-F10 melanoma cells
}

\author{
Chanuri-Yashara Dissanayake ${ }^{1}$, Hae-Hee Moon ${ }^{1}$, Kyeong-Mi Yang ${ }^{2}$, Younjae Lee ${ }^{1}$, Chang-Hoon Han ${ }^{1, *}$ \\ ${ }^{1}$ College of Veterinary Medicine, Jeju National University, Jeju 63243, Korea \\ ${ }^{2}$ Dahrum International Co., Ltd., Jeju National University Medium \& Small Business Center, Jeju 63243, Korea
}

(Received: February 17, 2018; Revised: May 1, 2018; Accepted: May 10, 2018)

\begin{abstract}
The present study observed the effects of a green tea (Camellia sinensis) flower extract (GTFE) on melanin synthesis in B16-F10 melanoma cells. GTFE exhibited antioxidant activity on 2,2-diphenyl-1-picrylhydrazyl and inhibited mushroom tyrosinase activity in a dose-dependent manner. Furthermore, GTFE significantly diminished $\alpha$ melanocyte stimulating hormone $(\alpha-\mathrm{MSH})$ stimulated cellular melanin content and tyrosinase activity throughout the concentration range evaluated. Based on RNA sequencing analysis, differential gene expression patterns observed in $\alpha$-MSH stimulated B16-F10 melanoma cells were normalized by the addition of GTFE. In particular, the expression levels of melanoregulin and tyrosinase genes which are key regulating genes in melanin synthesis were up-regulated by 3.5 and 3 fold respectively by $\alpha-\mathrm{MSH}$, and were normalized to control levels by the addition of GTFE. The results suggest that GTFE inhibits melanin synthesis in $\alpha$-MSH stimulated B16-F10 melanoma cells by normalizing expression of genes that are essential for melanin synthesis. Overall, the results suggest that GTFE could be applied in the development of a whitening agent for the treatment of dermal hyperpigmentation.
\end{abstract}

Keywords: B16-F10 melanoma cells, RNA sequencing analysis, antioxidant effect, green tea flower, melanin synthesis inhibition, tyrosinase activity inhibition

\section{Introduction}

Melanin is a well-known pigment which is commonly distributed and found in animals, plants, fungi and bacteria [17]. Melanocytes produce and pack melanin within melanosomes and transfer it to neighbouring keratinocytes in the epidermis, resulting in visible skin pigmentation which provide photoprotection and thermoregulation $[15,20]$. Melanogenesis is initiated with the oxidation of tyrosine to L-3,4-dihydroxyphenylalanine (L-DOPA) which is further oxidized into dopaquinone which is catalyzed by tyrosinase [5]. Therefore tyrosinase inhibitors can be clinically useful for the treatment of some dermatological disorders associated with melanin hyper pigmentation [2, 23].

Ultraviolet (UV) is a major melanogenesis factor that causes skin aging such as melasma, blackness lentigine, and age spots in the epidermis [14]. Since regulation of melanin synthesis is highly influenced by reactive oxygen species (ROS), UV-induced melanogenesis could be mitigated by ROS scavengers and ROS generator inhibitors [11]. Stimulation of antioxidant levels suppresses melanogenesis and therefore antioxidants are important in protecting human skin from UV radiation [28].

Undesired increase of melanin might be an aesthetic problem and recently there has been a continued interest in protecting healthy skin from persistent environmental pollution $[22,31]$. Hyperpigmentation has prompted the requirement of screening of a melonogenesis inhibitory agent. Skin lightening cosmetics made of plant-derived extracts has become a concern as commercially available skin whitening chemicals had adverse effects [3, 27].

The green tea is produced from the leaves of Camellia sinensis which contains high levels of flavonols, polyphenols and catechins $[6,21,37]$. Green tea is known to be one of the most active tyrosinase inhibitors with a major active constituents of epicatechin gallate (ECG), gallocatechin gallate (GCG), and epigallocatechin gallate (EGCG) which is a potential natural candidate for the hypopigmentation reagent [25]. Previous studies reported that EGCG in green tea (Camellia sinensis) flower extract (GTFE) attenuates microphthalmiaassociated transcription factor (MITF) and tyrosinase production in melanocytes meanwhile significantly suppressing melanin synthesis [16, 37].

In the present study, the inhibitory effects of GTFE on rad-

*Corresponding author

Tel: +82-64-754-3378, Fax: +82-64-756-3354

E-mail: chhan@jejunu.ac.kr 
ical production, tyrosinase activity, and melanin synthesis were observed. Particularly, the relationship between the melanogenesis and the differential expression of genes related to melanogenesis was explored to explain the hypopigmentation effect of GTFE.

\section{Materials and Methods}

\section{Materials}

$\alpha$-Melanocyte stimulating hormone ( $\alpha$-MSH), 2,2-diphenyl-1-picrylhydrazyl (DPPH), L-ascorbic acid (AA), L-DOPA, mushroom tyrosinase, and phenylmethylsulfonyl fluoride (PMSF), were purchased from Sigma Aldrich (USA). B16F10 mouse melanoma cell line was purchased from ATCC (USA), Triton X-100 from Bio-Rad Laboratories (USA), Dulbecco's modified Eagle's medium (DMEM) from Life Technologies (USA) and EZ-Cytox from DogenBio (Korea). All other reagents were purchased from commercial sources and were of the analytical grade.

\section{Preparation of GTFE}

Dried green tea flowers were purchased from Research Institute of Plant Resource (Korea) and was ground to a powder. GTF 100 g powder was soaked in $1 \mathrm{~L}$ of $80 \%$ ethanol (ethanol $/$ water $=80 / 20, \mathrm{v} / \mathrm{v}$ ) and was incubated in $60^{\circ} \mathrm{C}$ water bath for $1 \mathrm{~h}$ to facilitate extraction. The solvent was removed under reduced pressure in a rotary evaporator (HS-2005V, HanShin, Korea). The extract was filtered using Whatman No.1 filter paper, and the filtrate was diluted to final concentration of $50 \mathrm{mg} / \mathrm{mL}(\mathrm{w} / \mathrm{v})$.

\section{Cell culture and treatment}

B16-F10 cells were grown in monolayers, adherent to the bottom of culture flasks filled with DMEM supplemented with $10 \%$ fetal bovine serum and $1 \%$ penicillin-streptomycin at $37^{\circ} \mathrm{C}$ in a $5 \% \mathrm{CO}_{2}$ atmosphere. Cells were harvested in the exponential growth phase at $80 \%$ confluence. Cells were washed twice with PBS, exposed to trypsin EDTA solution for $30 \mathrm{sec}$ at $37^{\circ} \mathrm{C}$, centrifuged at $800 \times \mathrm{g}$ for $5 \mathrm{~min}$, and cells $\left(5 \times 10^{4}\right.$ cells/well $)$ were seeded in 96 -well plates.

\section{DPPH assay}

The antioxidant activity of GTFE was determined by measuring the DPPH free radical scavenging activity as described previously [14]. GTFE was dissolved in DMSO to make a series of concentrations (final concentration 0, 25, 50, 100, 200 , and $400 \mu \mathrm{g} / \mathrm{mL}$ ). Fifty microliters of each sample was mixed with $950 \mu \mathrm{L}$ of ethanolic $0.2 \mathrm{mM} \mathrm{DPPH}$ solution. The mixture was incubated at room temperature in dark condition for $30 \mathrm{~min}$, and the absorbance was measured at $525 \mathrm{~nm}$ using spectrophotometer (Mecasys, Korea). The radical scavenging ability (\%) of the samples was calculated as [1(absorbance of a group added to sample/absorbance of a group non-added to sample)] $\times 100$ and calculated as an effective concentration $\left(\mathrm{EC}_{50}\right)$, the concentration of sample needed to scavenge $\mathrm{DPPH}$ free radicals by $50 \% . \mathrm{EC}_{50}$ of GTFE was expressed as ascorbic acid equivalent antioxidant capacity (AEAC). AEAC (mg AA/100 g sample) $=\mathrm{EC}_{50}(\mathrm{AA}) /$ $\mathrm{EC}_{50}$ (sample) $\times 10^{5}$ [26]. The $\mathrm{EC}_{50}$ of AA used for the calculation of AEAC was $0.0062 \mathrm{mg} / \mathrm{mL}$.

\section{Cell viability assay (MTT assay)}

Cell viability assay in the presence of GTFE was analyzed using B16-F10 melanoma cells as described previously [30]. B16-F10 melanoma cells $\left(1 \times 10^{4}\right.$ cells/well $)$ were cultured in 96-well plates. Following $24 \mathrm{~h}$ of cell incubation, DMEM medium was removed and cells were treated with $0,25,50$, $100,200,400$ and $1,000 \mu \mathrm{g} / \mathrm{mL}$ of GTFE for $24 \mathrm{~h}$. Then $20 \mu \mathrm{L}$ of EZ-Cytox solution was treated for $2 \mathrm{~h}$ and absorbance values were measured at a $540 \mathrm{~nm}$ using ELISA microplate reader (Tecan, Switzerland).

\section{Mushroom tyrosinase assay}

The inhibitory effect of GTFE on, mushroom tyrosinase activity was measured as described previously [29]. One hundred thirty microliters of varying concentrations of GTFE samples $0,25,50,100,200,400$ and $1,000 \mu \mathrm{g} / \mathrm{mL}$ were mixed with $20 \mu \mathrm{L}$ of mushroom tyrosinase $(1250 \mathrm{U} / \mathrm{mL})$ in 96-well micro plate. Mixtures were incubated with $120 \mu \mathrm{L}$ of $1.5 \mathrm{mM} \mathrm{L}-\mathrm{DOPA}$ at $37^{\circ} \mathrm{C}$ for $5 \mathrm{~min}$ and absorbance was measured at $490 \mathrm{~nm}$ using ELISA micro plate reader.

\section{Cellular melanin synthesis inhibition assay}

Melanin contents were measured as previously described [33]. B16-F10 cells were seeded with $1 \times 10^{5}$ cells/well in $3 \mathrm{~mL}$ of medium in 6 well plates, and incubated overnight to allow cells to adhere. The cells were incubated with various concentrations $(0,5,10,20$, and $40 \mu \mathrm{g} / \mathrm{mL})$ of GTFE in the presence or absence of $20 \mathrm{nM} \alpha-\mathrm{MSH}$ for 2 days. Microscopic images of $\alpha$-MSH-stimulated B16-F10 melanoma cells incubated with various concentration of GTFE were captured using an inversed biological microscope connected HD LCD Tablet camera (Neoscience, Korea). Then cells were washed twice with PBS and were harvested through trypsinization with $1 \mathrm{~mL}$ of $1 \times$ EDTA and $1 \mathrm{~mL}$ of media. Cells were harvested by centrifugation $(800 \times \mathrm{g}$ for $5 \mathrm{~min})$ and pellets were dried at $60^{\circ} \mathrm{C}$ oven. Cells were lysed with $500 \mu \mathrm{L}$ of $1 \mathrm{M}$ $\mathrm{NaOH}$ containing $10 \%$ DMSO for $30 \mathrm{~min}$ at $80^{\circ} \mathrm{C}$ in a heating block and was briefly centrifuged $(800 \times \mathrm{g}$ for $1 \mathrm{~min})$. Supernatant $(300 \mu \mathrm{L})$ was added into wells of 96-well plates, and the absorbance at $490 \mathrm{~nm}$ was measured using an ELISA plate reader.

\section{Cellular tyrosinase inhibition assay}

Cellular tyrosinase activity was measured as described previously [9]. Six well plates were seeded with B16-F10 melanoma cells $\left(1 \times 10^{5}\right.$ cells/well $)$ in $3 \mathrm{ml}$ of media. Plates were incubated for $24 \mathrm{~h}$ at $37^{\circ} \mathrm{C}$ in a $\mathrm{CO}_{2}$ incubator, and were exposed to increasing doses of test extracts $(0,5,10,20$, and $40 \mu \mathrm{g} / \mathrm{mL}$ ) for $48 \mathrm{~h}$ in the presence or absence of $20 \mathrm{nM} \alpha$ - 
MSH. Cells were washed twice with PBS and were lysed in $500 \mu \mathrm{L}$ of PBS containing $1 \%$ Triton X-100 and $2 \mathrm{mM}$ PMSF, and stored at $-80^{\circ} \mathrm{C}$ for $30 \mathrm{~min}$ to facilitate cell rupturing. After thawing at room temperature, cell extracts were separated by centrifugation at $15,000 \times \mathrm{g}$ for $30 \mathrm{~min}$ at $4^{\circ} \mathrm{C}$. The supernatant $(150 \mu \mathrm{L})$ was mixed with $2 \mathrm{mM} \mathrm{L}-\mathrm{DOPA} 150 \mu \mathrm{L}$ in a 96-well plate, incubated $37^{\circ} \mathrm{C}$ for $10 \mathrm{~min}$, and the absorbance at $490 \mathrm{~nm}$ was measured using an ELISA plate reader.

Total RNA isolation, library preparation, sequencing and data analysis

B16-F10 cells were cultured in 6 well plates $\left(1 \times 10^{5}\right.$ cells/ well) and incubated at $37^{\circ} \mathrm{C}$, for $24 \mathrm{~h}$. Cells were washed with $1 \times$ PBS, and treated with $\alpha-\mathrm{MSH}$ and different concentrations of GTFE. Total RNA was separated from melanoma cells after $48 \mathrm{~h}$ cultivation and cells were dissolved in $500 \mu \mathrm{L}$ of Trizol reagent (Invitrogen, USA) according to manufacturer's instructions, and stored at $-80^{\circ} \mathrm{C}$ until use. RNA quality was assessed by Agilent 2100 Bioanalyzer using the RNA 6000 Nano Chip (Agilent Technologies, The Netherlands), and RNA quantification was carried out using ND-2000 Spectrophotometer (Thermo Fisher Scientific, USA). SENSE 3' mRNA-Seq Library Prep Kit (Lexogen, Austria) was used to perform the construction of a library for control and test RNAs according to the manufacturer's instructions. Total RNA 500 ng was prepared and an oligo-dT primer containing an Illumina-compatible sequence at its $5^{\prime}$ end was hybridized to the RNA and reverse transcription was performed. Following RNA degradation complimentary strand synthesis was started by random primer containing an Illumina-compatible linker sequence at its $5^{\prime}$ end. Magnetic beads were used to remove all reaction components. The library was amplified to add the complete adapter sequences required for cluster generation. The completed library was purified from PCR components. High-throughput sequencing was performed as single-end 75 sequencing using NextSeq 500 (Illumina, USA). SENSE 3' mRNA-Seq reads were aligned using Bowtie2 ver. 2.1.0 [18]. Bowtie2 indices were either generated from genome assembly sequence or the representative transcript sequences for aligning to the genome and transcriptome. The alignment file was used for assembling transcripts, estimating their abundances and detecting differential expression of genes. Differentially expressed genes were determined based on counts from unique and multiple alignments using EdgeR within $\mathrm{R}$ ver. 3.2.2 ( $\mathrm{R}$ development Core Team, 2011) using Bioconductor ver. 3.0 [12]. The read count data were processed based on Quantile normalization method using the Genowiz ver. 4.0.5.6 (Ocimum Biosolutions, India). Cytoscape (ver. 2.7), an open source bioinformatics platform developed by the Institute of Systems Biology, USA, was used to construct network diagrams and to illustrate clustering of the genes in our dataset within specific pathways. Gene classification was based on searches done by MEDLINE databases (National Centre for Biotechnology Information, USA).

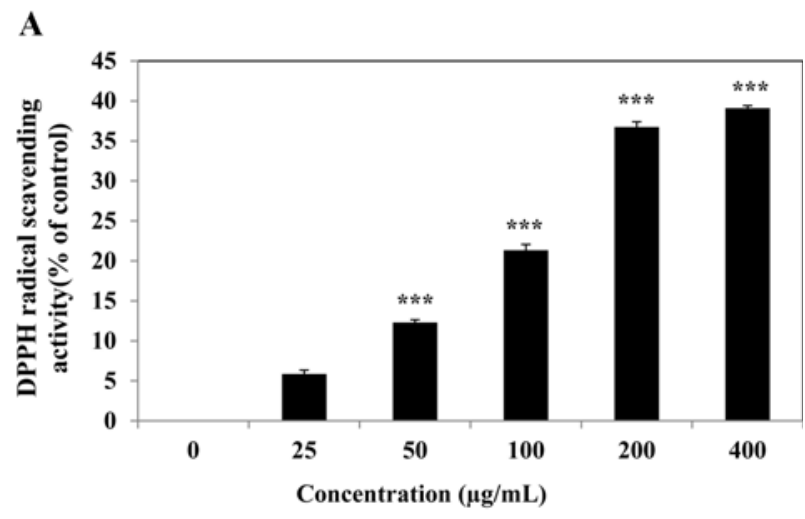

B

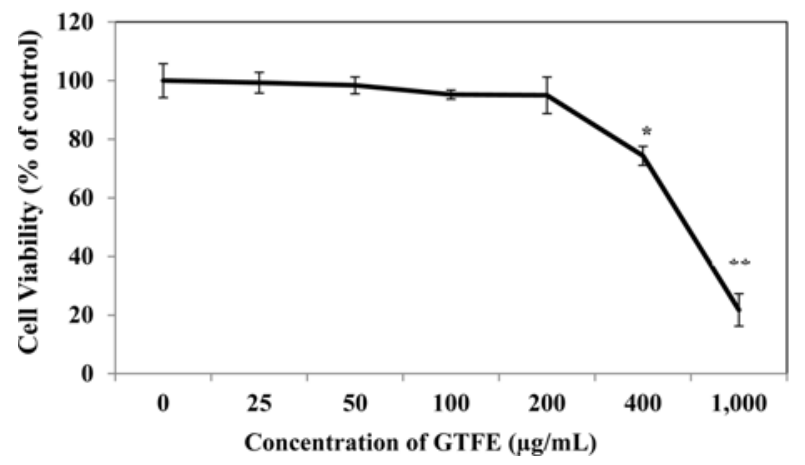

Fig. 1. Effects of green tea (Camellia sinensis) flower extract (GTFE) on 2,2-diphenyl-1-picrylhydrazyl (DPPH) radical scavenging activity and B16-F10 melanoma cells viability. (A) DPPH radical scavenging activity by different concentrations of GTFE. (B) B16-F10 melanoma cell viability by different concentrations of GTFE. Data are the means of \pm SE for three independent experiments. ${ }^{*} p<0.01, * * p<0.001 * * * p<0.0001 \mathrm{com}-$ pared with the control).

\section{Data analysis}

All experiments were done in triplicates or more, and the results were expressed as mean \pm standard error for each sample concentration. Data were statistically analyzed with SPSS Statistics (Ver. 17.0; IBM, USA). The statistical differences among groups were analyzed with one way analysis (ANOVA) followed by Turkey's test.

\section{Results}

\section{Radical scavenging activity}

DPPH assay was performed to evaluate the antioxidant activity of GTFE. GTFE displayed DPPH free radical scavenging activity in a dose dependent manner. DPPH radical scavenging activities of 25, 50,100, 200 and $400 \mu \mathrm{g} / \mathrm{mL}$ of GTFE were estimated to be $5.8 \%, 11.7 \%, 20.6 \%, 34.8 \%$ and $40.5 \%$ respectively (Fig. 1A). The $\mathrm{EC}_{50}$ of GTFE was estimated to be $0.266 \mathrm{mg} / \mathrm{mL}$, which is corresponding to $2328.58 \mathrm{mg}$ of $\mathrm{AA} / \mathrm{g}$ based on the ascorbic AEAC calculation as described in Materials and Methods. 


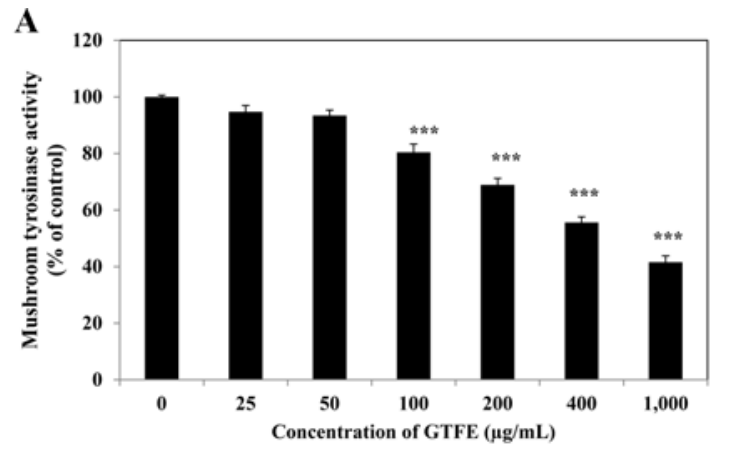

B

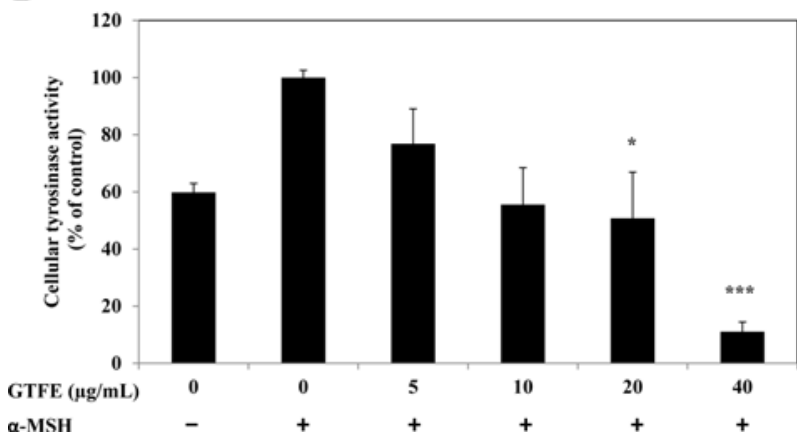

Fig. 2. Inhibitory effects of GTFE on mushroom tyrosinase activity and cellular tyrosinase activity. (A) Mushroom tyrosinase activity was examined at varying concentrations of GTFE. (B) Cellular tyrosinase activity in B16-F10 melanoma cell was observed after treatment of $\alpha$-melanocyte stimulating hormone $(\alpha-\mathrm{MSH})(20 \mathrm{nM})$ and varying concentrations of GTFE. Values represent the mean $\pm \mathrm{SE}$ for three independent experiments $\left({ }^{*} p<0.01,{ }^{* * *} p<0.0001\right.$ compared with the control).

\section{Cellular toxicity}

Cellular toxicity of GTFE on B16-F10 melanoma cells was measured using MTT assay. GTFE showed no cellular toxicity on B16-F10 melanoma cell at the concentration up to 200 $\mu \mathrm{g} / \mathrm{mL}$ (Fig. 1B). However, cellular toxicity was increased significantly $(25.6 \%)$ from the GTFE concentration of 400 $\mu \mathrm{g} / \mathrm{mL}$.

\section{Inhibition of mushroom tyrosinase activity}

Inhibitory effect of GTFE on mushroom tyrosinase activity was observed as described in Materials and Methods. As shown in Figure 2A, GTFE inhibited mushroom tyrosinase activity in a dose-dependent manner. Mushroom tyrosinase inhibition of $25,50,100,200,400$ and $1,000 \mu \mathrm{g} / \mathrm{mL}$ of GTFE was estimated to be $5.3 \%, 6.6 \%, 19.6 \%, 31.1 \%, 44.4 \%$ and $58.4 \%$ respectively (Fig. 2A).

\section{Inhibition of cellular tyrosinase activity}

Inhibitory effect of GTFE on cellular tyrosinase activity was evaluated in B16-F10 melanoma cells after stimulating melanin synthesis in cells using $\alpha-\mathrm{MSH}$. Cellular tyrosinase activity was significantly increased in the presence of $\alpha$ $\mathrm{MSH}$, whereas the activities were decreased in a concentra-
A

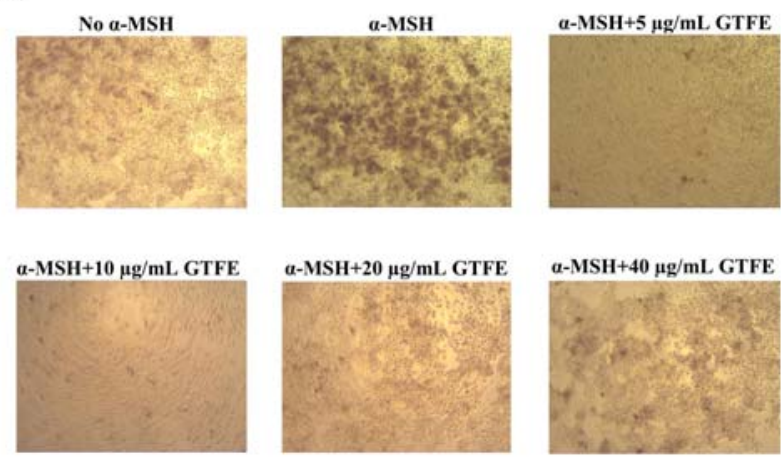

B

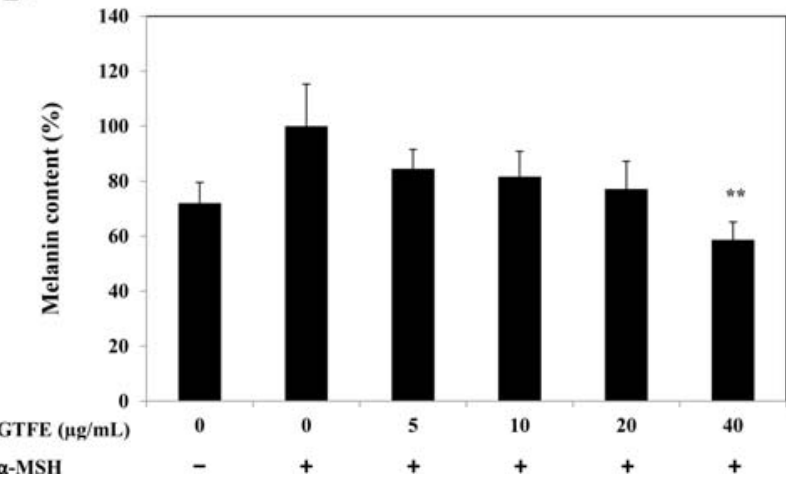

Fig. 3. Inhibitory effect of GTFE on $\alpha$-MSH-stimulated melanogenesis in B16-F10 melanoma cells. (A) Microscopic images of $\alpha$-MSH-stimulated B16-F10 melanoma cells incubated with varying concentration of GTFE. (B) Melanin content in $\alpha$ MSH-stimulated B16-F10 melanoma cells incubated with varying concentration of GTFE. Data are the means of \pm SE for four independent experiments. $\left({ }^{* *} p<0.001,{ }^{* * *} p<0.0001\right.$ compared with the control). $100 \times(\mathrm{A})$.

tion dependent manner of GTFE. GTFE 5, 10, 20 and $40 \mu \mathrm{g} /$ $\mathrm{mL}$ inhibited cellular tyrosinase activity by $23.2 \%, 44.4 \%$, $49.3 \%$ and $89.0 \%$ respectively (Fig. $2 \mathrm{~B}$ ).

\section{Inhibition of melanin synthesis}

Inhibitory effect of GTFE on melanin synthesis was observed in B16-F10 melanoma cells after stimulating melanin synthesis in cells using $\alpha$-MSH. Melanin synthesis was significantly increased in the presence of $\alpha-\mathrm{MSH}$, whereas declining trend of melanin was observed throughout the concentration range evaluated (Fig. 3A and B). GTFE 5, 10, 20 and $40 \mu \mathrm{g} / \mathrm{mL}$ suppressed melanin synthesis by $15.5 \%, 18.4 \%$, $22.9 \%$ and $41.3 \%$ respectively (Fig. 3B).

\section{Differential gene expression}

The differential gene expression of B16-F10 cells treated with $\alpha-\mathrm{MSH}$ and GTFE were observed using RNA sequencing analysis. Based on RNA sequencing results, among 23,282 of total genes in B16-F10 cells, 2,420 genes were upregulated (higher than 2.0) and 3,236 genes were down-regu- 
Table 1. Differential expression of functional genes in B16-F10 melanoma cell treated with $\alpha-\mathrm{MSH}$ only

\begin{tabular}{|c|c|c|c|c|c|c|c|c|c|c|c|c|c|c|c|c|}
\hline & Total & A & Ang & AP & $\mathrm{CC}$ & $\mathrm{CD}$ & CDi & $\mathrm{CM}$ & $\mathrm{CP}$ & DR & EM & IR & InR & $\mathrm{N}$ & $\mathrm{RS}$ & $\mathrm{S}$ \\
\hline Gene number & 23282.0 & 265.0 & 303.0 & 775.0 & 1042.0 & 842.0 & 3287.0 & 695.0 & 549.0 & 377.0 & 406.0 & 881.0 & 417.0 & 1486.0 & 288.0 & 470.0 \\
\hline$\%$ of total & 100.0 & 1.1 & 1.3 & 3.3 & 4.5 & 3.6 & 14.1 & 3.0 & 2.4 & 1.6 & 1.7 & 3.8 & 1.8 & 6.4 & 1.2 & 2.0 \\
\hline Up significant & 2420.0 & 22.0 & 31.0 & 89.0 & 87.0 & 96.0 & 260.0 & 67.0 & 51.0 & 40.0 & 26.0 & 71.0 & 28.0 & 120.0 & 20.0 & 46.0 \\
\hline $\begin{array}{l}\% \text { of up } \\
\text { significant }\end{array}$ & 10.4 & 8.3 & 10.2 & 11.5 & 8.3 & 11.4 & 7.9 & 9.6 & 9.3 & 10.6 & 6.4 & 8.1 & 6.7 & 8.1 & 6.9 & 9.8 \\
\hline $\begin{array}{l}\text { Down } \\
\text { significant }\end{array}$ & 3236.0 & 38.0 & 41.0 & 115.0 & 225.0 & 122.0 & 436.0 & 93.0 & 77.0 & 92.0 & 51.0 & 95.0 & 52.0 & 210.0 & 48.0 & 57.0 \\
\hline $\begin{array}{l}\% \text { of down } \\
\text { significant }\end{array}$ & 13.9 & 14.3 & 13.5 & 14.8 & 21.6 & 14.5 & 13.3 & 13.4 & 14.0 & 24.4 & 12.6 & 10.8 & 12.5 & 14.1 & 16.7 & 12.1 \\
\hline
\end{tabular}

A, aging; Ang, angiogenesis; AP, apoptosis process; CC, cell cycle; CD, cell death; CDi, cell difference; $\mathrm{CM}$, cell migration; $\mathrm{CP}$, cell proliferation; DR, DNA repair; EM, extracellular matrix; IR, immune response; InR, inflamation response; N, neurogenesis; RS, RNA splicing; $\mathrm{S}$, secretion.

Table 2. Differential expression of functional genes in B16-F10 melanoma cell treated with $\alpha$-MSH and GTFE $(20 \mu \mathrm{g} / \mathrm{mL})$

\begin{tabular}{|c|c|c|c|c|c|c|c|c|c|c|c|c|c|c|c|c|}
\hline & Total & A & Ang & $\mathrm{AP}$ & $\mathrm{CC}$ & $\mathrm{CD}$ & CDi & $\mathrm{CM}$ & $\mathrm{CP}$ & DR & EM & IR & InR & $\mathrm{N}$ & $\mathrm{RS}$ & $\mathrm{S}$ \\
\hline Gene number & $23,282.0$ & 265.0 & 303.0 & 775.0 & $1,042.0$ & 842.0 & $3,287.0$ & 695.0 & 549.0 & 377.0 & 406.0 & 881.0 & 417.0 & $1,486.0$ & 288.0 & 470.0 \\
\hline$\%$ of total & 100.0 & 1.1 & 1.3 & 3.3 & 4.5 & 3.6 & 14.1 & 3.0 & 2.4 & 1.6 & 1.7 & 3.8 & 1.8 & 6.4 & 1.2 & 2.0 \\
\hline Up significant & $2,876.0$ & 21.0 & 38.0 & 77.0 & 89.0 & 87.0 & 264.0 & 74.0 & 50.0 & 32.0 & 52.0 & 80.0 & 26.0 & 135.0 & 28.0 & 50.0 \\
\hline $\begin{array}{l}\% \text { of up } \\
\text { significant }\end{array}$ & 12.4 & 7.9 & 12.5 & 9.9 & 8.5 & 10.3 & 8.0 & 10.6 & 9.1 & 8.5 & 12.8 & 9.1 & 6.2 & 9.1 & 9.7 & 10.6 \\
\hline $\begin{array}{l}\text { Down } \\
\text { significant }\end{array}$ & $2,697.0$ & 28.0 & 28.0 & 97.0 & 177.0 & 103.0 & 364.0 & 93.0 & 64.0 & 71.0 & 37.0 & 85.0 & 37.0 & 178.0 & 28.0 & 56.0 \\
\hline $\begin{array}{l}\% \text { of down } \\
\text { significant }\end{array}$ & 11.6 & 10.3 & 9.2 & 12.5 & 17.0 & 12.2 & 11.1 & 13.4 & 11.7 & 18.8 & 9.1 & 9.6 & 8.9 & 12.0 & 9.7 & 11.9 \\
\hline
\end{tabular}

Table 3. Differential expression of functional genes in B16-F10 melanoma cell treated with $\alpha-\mathrm{MSH}$ and GTFE (40 $\mu \mathrm{g} / \mathrm{mL})$

\begin{tabular}{|c|c|c|c|c|c|c|c|c|c|c|c|c|c|c|c|c|}
\hline & Total & A & Ang & AP & $\mathrm{CC}$ & $\mathrm{CD}$ & CDi & $\mathrm{CM}$ & $\mathrm{CP}$ & DR & EM & IR & InR & $\mathrm{N}$ & $\mathrm{RS}$ & $\mathrm{S}$ \\
\hline Gene number & 23282.0 & 265.0 & 303.0 & 775.0 & 1042.0 & 842.0 & 3287.0 & 695.0 & 549.0 & 377.0 & 406.0 & 881.0 & 417.01 & 486.0 & 288.0 & 470.0 \\
\hline$\%$ of total & 100.0 & 1.1 & 1.3 & 3.3 & 4.5 & 3.6 & 14.1 & 3.0 & 2.4 & 1.6 & 1.7 & 3.8 & 1.8 & 6.4 & 1.2 & 2.0 \\
\hline Up significant & 2454.0 & 20.0 & 26.0 & 76.0 & 73.0 & 82.0 & 265.0 & 70.0 & 47.0 & 36.0 & 72.0 & 72.0 & 22.0 & 129.0 & 20.0 & 48.0 \\
\hline$\%$ of up significant & 10.5 & 7.5 & 8.6 & 9.8 & 7.0 & 9.7 & 8.1 & 10.1 & 8.6 & 9.5 & 8.2 & 8.2 & 5.3 & 8.7 & 6.9 & 10.2 \\
\hline Down significant & 2624.0 & 31.0 & 40.0 & 93.0 & 227.0 & 103.0 & 359.0 & 91.0 & 73.0 & 85.0 & 86.0 & 86.0 & 51.0 & 174.0 & 39.0 & 41.0 \\
\hline $\begin{array}{l}\% \text { of down } \\
\text { significant }\end{array}$ & 11.3 & 11.7 & 13.2 & 12.0 & 21.8 & 12.2 & 10.9 & 13.1 & 13.3 & 22.5 & 9.8 & 9.8 & 12.2 & 11.7 & 13.5 & 8.7 \\
\hline
\end{tabular}

lated (lower than 0.5 ) in $\alpha$-MSH treated group compared to control group (Table 1). In contrast, 2,876 genes were upregulated and 2,697 genes were down-regulated in both $\alpha$ $\mathrm{MSH}$ and $20 \mu \mathrm{g} / \mathrm{mL}$ GTFE treated group compared to control group (Table 2). In addition, 2,454 genes were up-regulated and 2,624 genes were down-regulated in both $\alpha$-MSH and $40 \mu \mathrm{g} / \mathrm{mL}$ GTFE treated group compared to control group (Table 3).

Analysis of RNA sequencing data showed that 8 genes related to melanogenesis including Atp6v1g2, Try, Slcla4, Mreg, Cited1, Hspa5, Slc3a2 and Pdia4 genes were up-regulated by $44.9,3.5,3.0,3,2.8,2.6,2.2$ and 2.0 folds com- pared to the control group by addition of $\alpha$-MSH. However the levels were normalized to control level by the addition of GTFE (Fig. 4A). In particular, the expression levels of Mreg and Tyr genes which are key regulating genes in melanin synthesis were up-regulated by 3.5 and 3 fold compared to control group by $\alpha-\mathrm{MSH}$ and were normalized to control level by the addition of GTFE (Fig. 4A).

Seven genes related to melanin synthesis including Stom, Rab2a and Rab29 genes were down-regulated by 0.5, 0.4 and 0.4 fold compared to control group by $\alpha-\mathrm{MSH}$ and were normalized to control level by the addition of GTFE (Fig. 4B). 
$\mathbf{A}$

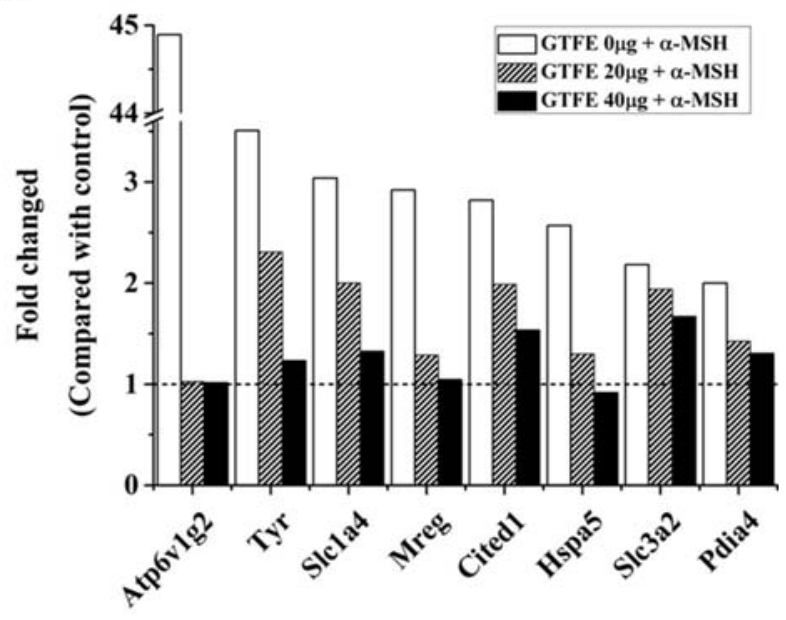

B

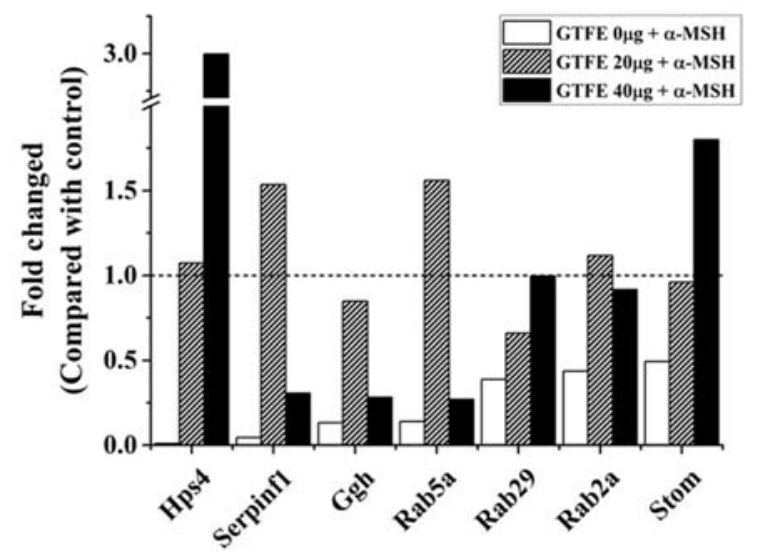

Fig. 4. Differential gene expressions in $\alpha$-MSH-stimulated B16F10 melanoma cells incubated with varying concentration of GTFE. Up-regulated (A) and down regulated (B) genes by $\alpha$ MSH which were normalized by GTFE treatment.

\section{Discussion}

Green tea is one of the most popular beverages in the world, and considered to have many scientifically proven beneficial effects on human health [6]. It has been reported that Camellia sinensis flowers have similar chemical compositions with Camellia sinensis leaves and GTFE contains a high amount of flavonoids, polyphenols, catechins, ECG and EGCG which directly scavenge free radicals and ROS [37]. However, despite many published results, the ameliorative effect of GTFE on melanogenesis has not been reported. In the present study, we investigated the effects of GTFE on melanin synthesis, and on the expression levels of genes related to melanin synthesis in B16-F10 melanoma cells.

Whitening efficacy of Camellia sinensis flower extract in B16-F10 melanoma cells was verified in the current study by radical scavenging assay, tyrosinase inhibition assay, and melanogenesis inhibition assay followed by the differential gene expression patterns. Significant radical scavenging ability, mushroom tyrosinase inhibition activity, $\alpha-\mathrm{MSH}$ stimulated B16-F10 melanoma cellular melanin content, and cellular tyrosinase activity inhibition were expressed by GTFE concentration dependently.

The present study observed that GTFE scavenged DPPH radicals in a dose dependent manner. As observed previously, the skin exposure to UV radiation generates both melanin and harmful amount of ROS [4]. As ROS are essential in melanocyte proliferation and melanogenesis, ROS scavengers will reduce hyperpigmentation and UV-induced melanogenesis [36]. Overall results suggest that the radical scavenging effect of GTFE might contribute to the inhibition of melanogenesis in cells.

Previous studies revealed that ECG, GCG, and EGCG, the major components of green tea, are the most effective tyrosinase inhibitors $[17,25]$. In the present study GTFE showed inhibitory effect on both mushroom tyrosinase activity and cellular tyrosinase activity. GTFE inhibited mushroom tyrosinase activity in a cell-free system revealing the direct inhibitory effects of GTFE on tyrosinase activity. The results suggest that the components of GTFE directly inhibit cellular tyrosinase activity, and mainly contribute to the reduction of pigments in melanoma cells.

In $\alpha$-MSH stimulated B16-F10 melanoma cells, the expression levels of Mreg and Tyr genes which are key regulating genes in melanin synthesis were up-regulated by 3.5 and 3 fold respectively by $\alpha-\mathrm{MSH}$, and were normalized to control level by addition of GTFE, which normalized the melanin synthesis and its transport.

Tyr gene is a key regulating gene in the initial steps of melanin synthesis by catalyzing the oxidation of tyrosine to DOPA quinone [32]. Mreg gene is known to be essential for the lysosome maturation, intracellular trafficking and vesicular transporting of pigments in epithelial cells [10]. In addition, the gene expression levels of other genes related to melanogenesis including Slc1a4, Hspa5 and Cited1 were upregulated by $\alpha-\mathrm{MSH}$ and were restored to control level by GTFE.

Slc1a4 is a target gene of MITF which is involved in amino acid and lipid metabolism in melanocytes [13]. Hspa5 is known to protect tyrosinase as a molecular chaperone [32]. Cited1 plays a vital role in melanogenesis by regulating tyrosinase, dopachrome tautomerase and more enzymes in pigmentary system [24]. In the present study, GTFE was found to restore $\alpha-\mathrm{MSH}$ induced up-regulated gene expression levels of the genes related to melanogenesis including Atp6v1g2, Tyr, Slc1a4, Mreg, Cited1, Hspa5, Slc3a2 and Pdia4 in B16F10 melanoma cells to the control level upholding the antimelanogenesis effect of GTFE.

Microarray studies further showed that the expression levels of 3 genes including Stom, Rab2a and Rab29 which are related to melenogenesis were down-regulated by $\alpha-\mathrm{MSH}$ and were normalized by GTFE. A lipid raft-associated protein 
Stom gene which involves in melanosome degradation $[7,8$, 19] and golgi complex regulating genes Rab29 and Rab2a which contribute to the proteolysis of tyrosinase were downregulated by $\alpha-\mathrm{MSH}$ and were restored by GTFE hindering skin pigmentation $[1,2,34,35]$. Therefore, the results indicate that components of GTFE normalized the expression of genes related to melanogenesis which were disturbed by $\alpha-\mathrm{MSH}$.

In conclusion, this study explored that GTFE inhibits the cellular tyrosinase activity and melanin synthesis in $\alpha$-MSH stimulated B16-F10 cells by regulating genes related to melanogenesis. The overall results suggest that GTFE can be applied for the development of whitening agent for the treatment of dermal hyperpigmentation.

\section{Acknowledgments}

This study was supported by the 2017 scientific promotion program funded by Jeju National University, Korea.

\section{References}

1. Aizawa M, Fukuda M. Small GTPase Rab2B and its specific binding protein Golgi-associated Rab2B interactorlike 4 (GARI-L4) regulate Golgi morphology. J Biol Chem 2015, 290, 22250-22261.

2. Ando H, Kondoh H, Ichihashi M, Hearing VJ. Approaches to identify inhibitors of melanin biosynthesis via the quality control of tyrosinase. J Invest Dermatol 2007, 127, 751-761.

3. Briganti S, Camera E, Picardo M. Chemical and instrumental approaches to treat hyperpigmentation. Pigment Cell Res 2003, 16, 101-110.

4. Campos PM, da Silva Horinouchi CD, da Silveira Prudente A, Cechinel-Filho V, de Almeida Cabrini D, Otuki MF. Effect of a Garcinia gardneriana (Planchon and Triana) Zappi hydroalcoholic extract on melanogenesis in B16F10 melanoma cells. J Ethnopharmacol 2013, 148, 199-204.

5. Chang TS. An updated review of tyrosinase inhibitors. Int J Mol Sci 2009, 10, 2440-2475.

6. Chatterjee A, Saluja M, Agarwal G, Alam M. Green tea: a boon for periodontal and general health. J Indian Soc Periodontol 2012, 16, 161-167.

7. Chi A, Valencia JC, Hu ZZ, Watabe H, Yamaguchi H, Mangini NJ, Huang H, Canfield VA, Cheng KC, Yang F, Abe R, Yamagishi S, Shabanowitz J, Hearing VJ, Wu C, Appella E, Hunt DF. Proteomic and bioinformatic characterization of the biogenesis and function of melanosomes. $\mathrm{J}$ Proteome Res 2006, 5, 3135-3144.

8. Choi B, Heo JH, Kwon HJ, Lee ES, Sohn S. Tocotrienols enhance melanosome degradation through endosome docking/ fusion proteins in B16F10 melanoma cells. Food Funct 2013, 4, 1481-1488.

9. Chung KW, Park YJ, Choi YJ, Park MH, Ha YM, Uehara Y, Yoon JH, Chun P, Moon HR, Chung HY. Evaluation of in vitro and in vivo anti-melanogenic activity of a newly synthesized strong tyrosinase inhibitor $(E)-3-(2,4$ dihydroxybenzylidene)pyrrolidine-2,5-dione (3-DBP). Biochim Biophys Acta 2012, 1820, 962-969.
10. Damek-Poprawa M, Diemer T, Lopes VS, Lillo C, Harper DC, Marks MS, Wu Y, Sparrow JR, Rachel RA, Williams DS, Boesze-Battaglia K. Melanoregulin (MREG) modulates lysosome function in pigment epithelial cells. $\mathrm{J}$ Biol Chem 2009, 284, 10877-10889.

11. Funasaka Y, Chakraborty AK, Komoto M, Ohashi A, Ichihashi M. The depigmenting effect of a-tocopheryl ferulate on human melanoma cells. Br J Dermatol 1999, 141, 20-29.

12. Gentleman RC, Carey VJ, Bates DM, Bolstad B, Dettling M, Dudoit S, Ellis B, Gautier L, Ge Y, Gentry J, Hornik K, Hothorn T, Huber W, Iacus S, Irizarry R, Leisch F, Li C, Maechler M, Rossini AJ, Sawitzki G, Smith C, Smyth G, Tierney L, Yang JY, Zhang J. Bioconductor: open software development for computational biology and bioinformatics. Genome Biol 2004, 5, R80.

13. Guyonneau L, Murisier F, Rossier A, Moulin A, Beermann F. Melanocytes and pigmentation are affected in dopachrome tautomerase knockout mice. Mol Cell Biol 2004, 24, 33963403.

14. Huang HC, Lien HM, Ke HJ, Chang LL, Chen CC, Chang TM. Antioxidative characteristics of Anisomeles indica extract and inhibitory effect of ovatodiolide on melanogenesis. Int J Mol Sci 2012, 13, 6220-6235.

15. Joshi PG, Nair N, Begum G, Joshi NB, Sinkar VP, Vora S. Melanocyte-keratinocyte interaction induces calcium signalling and melanin transfer to keratinocytes. Pigment Cell Res 2007, 20, 380-384.

16. Kim DS, Park SH, Kwon SB, Li K, Youn SW, Park KC. (-)-Epigallocatechin-3-gallate and hinokitiol reduce melanin synthesisvia decreased MITF production. Arch Pharm Res 2004, 27, 334-339.

17. Kim YC, Choi SY, Park EY. Anti-melanogenic effects of black, green, and white tea extracts on immortalized melanocytes. J Vet Sci 2015, 16, 135-143.

18. Langmead B, Salzberg SL. Fast gapped-read alignment with Bowtie 2. Nat Methods 2012, 9, 357-359.

19. Lee JH, Hsieh CF, Liu HW, Chen CY, Wu SC, Chen TW, Hsu CS, Liao YH, Yang CY, Shyu JF, Fischer WB, Lin CH. Lipid raft-associated stomatin enhances cell fusion. FASEB J 2017, 31, 47-59.

20. Lin JY, Fisher DE. Melanocyte biology and skin pigmentation. Nature 2007, 445, 843-850.

21. Lin YS, Wu SS, Lin JK. Determination of tea polyphenols and caffeine in tea flowers (Camellia sinensis) and their hydroxyl radical scavenging and nitric oxide suppressing effects. J Agric Food Chem 2003, 51, 975-980.

22. Lobo V, Patil A, Phatak A, Chandra N. Free radicals, antioxidants and functional foods: Impact on human health. Pharmacogn Rev 2010, 4, 118-126.

23. Mustapha N, Bzéouich IM, Ghedira K, Hennebelle T, Chekir-Ghedira L. Compounds isolated from the aerial part of Crataegus azarolus inhibit growth of B16F10 melanoma cells and exert a potent inhibition of the melanin synthesis. Biomed Pharmacother 2015, 69, 139-144.

24. Nair SS, Chaubal VA, Shioda T, Coser KR, Mojamdar M. Over-expression of MSG1 transcriptional co-activator increases melanin in B16 melanoma cells: a possible role for MSG1 in melanogenesis. Pigment Cell Res 2001, 14, 206-209.

25. No JK, Soung DY, Kim YJ, Shim KH, Jun YS, Rhee SH, Yokozawa T, Chung HY. Inhibition of tyrosinase by green 
tea components. Life Sci 1999, 65, PL241-246.

26. Rabeta M, Vithyia M. Effect of different drying methods on the antioxidant properties of Vitex negundo Linn. tea. Int Food Res J 2013, 20, 3171-3176.

27. Roh JS, Han JY, Kim JH, Hwang JK. Inhibitory effects of active compounds isolated from safflower (Carthamus tinctorius L.) seeds for melanogenesis. Biol Pharm Bull 2004, 27, 1976-1978.

28. Sasaki M, Kizawa K, Igarashi S, Horikoshi T, Uchiwa H, Miyachi Y. Suppression of melanogenesis by induction of endogenous intracellular metallothionein in human melanocytes. Exp Dermatol 2004, 13, 465-471.

29. Serafini M, Ghiselli A, Ferro-Luzzi A. In vivo antioxidant effect of green and black tea in man. Eur J Clin Nutr 1996, 50, 28-32.

30. Shon MS, Kim RH, Kwon OJ, Roh SS, Kim GN. Beneficial role and function of fisetin in skin health via regulation of the $\mathrm{CCN}_{2} /$ TGF- $\beta$ signaling pathway. Food Sci Biotechnol 2016, 25 (Suppl 1), 133-141.

31. Solano F, Briganti S, Picardo M, Ghanem G. Hypopigmenting agents: an updated review on biological, chemical and clinical aspects. Pigment Cell Res 2006, 19, 550-571.

32. Tang H, Zhou P. Heat shock protein Hspa5 interacts with and protects tyrosinase activity. Braz Arch Biol Technol2015, 58, 547-552.

33. Tsuboi T, Kondoh H, Hiratsuka J, Mishima Y. Enhanced melanogenesis induced by tyrosinase gene-transfer increases boron-uptake and killing effect of boron neutron capture therapy for amelanotic melanoma. Pigment Cell Res 1998, 11, 275-282.

34. Wang S, Ma Z, Xu X, Wang Z, Sun L, Zhou Y, Lin X, Hong W, Wang T. A role of Rab29 in the integrity of the trans-Golgi network and retrograde trafficking of mannose-6phosphate receptor. PLoS One 2014, 9, e96242.

35. Wellings SR, Siegel BV. Role of Golgi apparatus in the formation of melanin granules in human malignant melanoma. J Ultrastruct Res 1959, 3, 147-154.

36. Yamakoshi J, Otsuka F, Sano A, Tokutake S, Saito M, Kikuchi M, Kubota Y. Lightening effect on ultravioletinduced pigmentation of guinea pig skin by oral administration of a proanthocyanidin-rich extract from grape seeds. Pigment Cell Res 2003, 16, 629-638.

37. Yang Z, Xu Y, Jie G, He P, Tu Y. Study on the antioxidant activity of tea flowers (Camellia sinensis). Asia Pac J Clin Nutr 2007, 16 (Suppl 1), 148-152. 